\title{
Constitutionalizing Women's Equality
}

\author{
Kathleen M. Sullivan†
}

\section{I \\ THE OMISSION OF WOMEN FROM THE U.S. CONSTITUTION}

The U.S. Constitution is the only major written constitution that includes a bill of rights but lacks a provision explicitly declaring the equality of the sexes. Since 1946 the French Constitution has provided that "[t]he law guarantees to the woman, in all spheres, rights equal to those of the man." Article 3 of the German Constitution declares that "[m]en and women have equal rights," and that "[n]obody shall be prejudiced or favored because of their sex ...."2 The Constitution of India provides that "the State shall not discriminate against any citizen on grounds only of ... sex ...."3 Among newer constitutions, Canada's states that "[e]very individual is equal before and under the law and has the right to the equal protection and equal benefit of the law without discrimination based on ... sex...." South Africa's provides that neither the state nor any person may "unfairly discrimmate directly or indirectly against anyone on ... grounds including...gender, sex, pregnancy, [or] marital status ....."

In contrast, the U.S. Constitution, in its original text, never referred to women at all. The only known use of the pronoun "she" in the framing deliberations concerned a later-rejected clause that would have referred to the

Copyright $\odot 2002$ California Law Review, Inc. California Law Review, Inc. (CLR) is a California nonprofit corporation. CLR and the authors are solely responsible for the content of their publications.

$\dagger$ Dean and Richard E. Lang Professor and Stanley Morrison Professor, Stanford Law School. This Article is based on the Brennan Lectures delivered at the Jorde Brennan Symposium at Boalt Hall School of Law, University of California at Berkeley, on November 30, 2000, and at New York University Law School on April 3, 2001. The author thanks Mary Anne Case, Michael Dorf, Susan Estrich, and Lawrence Sager for their very thoughtful and provocative commentaries, and Joshua Klein for excellent research assistance.

1. FR. Const. (Preamble to 1946 Constitution) ๆ 3, in Raymond Youngs, English, French and German Comparative Law 147 (1998). The preamble to the 1946 Constitution has been incorporated into the current constitution, adopted in 1958. See Fr. Const. (1958) pinbl.

2. F.R.G. Const. (official translation, 1994) ch. 1, art. 3, reprinted in 7 ConstituTions of THE CoUNTRIES OF THE WORLD (Gisbert H. Flanz ed., 1994).

3. INDIA CONST. art. 15, \$1 (1950).

4. CAN. Const. (Constitution Act, 1982) pt. 1 (Canadian Charter of Rights and Freedouns), $\S 15$.

5. S. AFr. Const. ch. 2 (Bill of Rights), $\$ 9$ (1996). 
rendition of fugitive slaves. ${ }^{6}$ Of course, some clauses, such as the habeas corpus, ${ }^{7}$ ex post facto,${ }^{8}$ and bills of attainder ${ }^{9}$ clauses, must have applied implicitly to women for they accord personal rights that make no exclusion on the basis of gender. The Constitution provided no explicit protection, however, against laws that disenfranchised women, excluded them from juries, barred married women from owning property or suing in their own capacity, and the like. ${ }^{10}$

The Fourteenth Amendment added the provision that no state shall deprive any person of the "equal protection of the laws," or of the "privileges and immunities" of federal citizenship. ${ }^{11}$ Nothing in that provision, however, appeared at its ratification to contemplate equality for woinen. Indeed, Section 2 of the Fourteenth Amendment, to the horror of contemporary suffragists who had also fought for abolition, ${ }^{12}$ introduced the word "male" into the Constitution and linked it to the franchise, providing for the apportionment of representatives among states by population but penalizing states that limited the vote of noncriminal "male" inhabitants. ${ }^{13}$

6. See Walter E. Dellinger III, 1787: The Constitution and "the Curse of Heaven", 29 WM. \& Mary L. Rev. 145, 153 (1987) (citing and discussing 1 The Records of the Federal Convention of 1787, at 453-54 (Max Farrand ed., 1911)). The Fugitive Slave Clause as eventually adopted uses only the masculine pronoun "he." U.S. ConST. art IV, $\$ 2$, cl. 2.

7. U.S. CONST. art. I, $\S 9$, cl. 2.

8. U.S. CoNST. art. $1, \S 9, \mathrm{cl} .3$.

9. $1 d$.

10. See, e.g., Frontiero v. Richardson, 411 U.S. 677, 685 (1973) ("[W]omen could [not] hold office, serve on juries, or bring suit in their own names, and married women traditionally were denied the legal capacity to hold or convey property or to serve as legal guardians of their own children.").

The common law limitations are further summarized in Homer H. ClaRK, JR., THE LAW OF DOMESTIC RELATIONS IN THE UNITED STATES 219-20 (1st ed. 1968). In addition, salient portions of the 1846 treatise on domestic relations, written by American legal authority Tapping Reeve, are briefly summarized in LiNDA K. KeRBER, No CONSTITUTIONAL RIGHT to BE LADIES: Women AND THE Obligations of Citizenship 13-15 (1998); see also Herma Hill Kay, From the Second Sex to the Joint Venture: An Overview of Women's Rights and Family Law in the United States During the Twentieth Century, 88 CaLIF. L. REv. 2017, 2021 (2000) ("Blackstone's mid-eighteenth century description of the English law of marriage as subsunning the legal personality of the wife into that of the husband so that the two became one was considered to be the defining characteristic of the American common law of marriage as well.").

Reform of discrimimatory systems in the nineteenth century proceeded not via constitutional challenge, but rather through statutes enacted at the state level, such as the Married Women's Property Acts, the first of which was enacted in 1839 in Mississippi. See LAWRENCE M. FrIEDMAN, A History of AMERICAN LAw 209-10 (2d ed. 1985). But these law reform efforts were limited; when Leo Kanowitz surveyed the law's treatment of married women in 1969, he found numerons examples of state laws burdening women's ability to contract or to undertake business activities separate from her husband. Leo KanowitZ, WOMEN aNd the Law: The UNFinished Revolution 55-59 (1969).

11. U.S. CoNST. amend. XIV, $\S 1$.

12. See Eleanor Flexner, A Century of Struggle: The Woman's Rights Movement in THE UNITEd STATES 146 (1975) ("Women with the acumen of Mrs. Stanton, Miss Anthony, and Mrs. Stone were naturally appalled at the appearance, for the first time, of the word 'male' in the Constitution ... in counection with the term 'citizen'....").

13. The Fourteenth Amcndment states: 
The Supreme Court soon confirmed that the majestic guarantees of Section 1 of the Fourteenth Amendment did not apply to women, even women challenging express formal discrimination. In 1872, the Court rejected the idea that federal privileges and immunities included any right for Myra Bradwell to practice law in Illinois. ${ }^{14}$ The Court's opinion was founded on the view, derived from the previous day's opinion in the Slaughter-House Cases, ${ }^{15}$ that the right to practice law was not a privilege of federal citizenship at all. ${ }^{16}$ Even so, those Justices who would have found such a privilege in the Slaughter-House Cases ${ }^{17}$ wrote in Bradwell that such a privilege would have applied only to inen. "It certainly cannot be affirmed, as an historical fact,"18 Justice Bradley wrote, that "it is one of the privileges and immunities of woinen as citizens to engage in any and every profession, occupation, or employment in civil life."19

The next year, in Minor v. Happersett, ${ }^{20}$ the Court held that federal privileges and immunities did not include women's right to vote in state elections. The Court suggested that although women were persons, and hence citizens, within the meaning of the Fourteenth Amendment, the right to vote was, like the occupational right claimed in Bradwell, not a privilege or immunity. Hence, the states could, if they chose, reserve the political and professional realms to men. ${ }^{21}$

The only provision of the U.S. Constitution that addresses woinen's equality specifically is the Nineteenth Amendment, ratified in 1920, which provides that "[t]he right of citizens of the United States to vote shall not be denied or abridged by the United States or by any State on account of sex."22 That provision, however, has been construed narrowly as applying only to the formal franchise. When women atteinpted to use the Nineteenth Amendment as a broader litigating tool, various state courts rejected the

[W] hen the right to vote at any election for the choice of electors for President and Vice President of the United States, Representatives in Congress, the executive and judicial officers of a State, or the meunbers of the legislature thereof, is denied to any of the male inhabitants of such State, being twenty-one years of age, and citizens of the United States, or in any way abridged, ... the basis of representation therein shall be reduced in the proportion which the number of such male citizens shall bear to the whole number of nuale citizens twenty-one years of age in such state.

U.S. ConsT. amend. XIV, $\$ 2$.

14. Bradwell v. lllinois, 83 U.S. (16 Wall.) 130 (1872).

15. 83 U.S. 36 (16 Wall.) (1872).

16. Bradwell, 83 U.S. at 139.

17. Justice Bradley wrote in the Slaughter-House Cases that "the right of any citizen to follow whatever lawful enployment he chooses to adopt" is "one of his most valuable rights." SlaughterHouse Cases, 83 U.S. 36, 113-14 (1872) (Bradley, J., dissenting). In light of Bradwell, Bradley's choice of words here appears "evidently ... not merely a unatter of stylistic convention." LAURENCE H. TRIBE, AMERican Constitutional Law 1559 n.3 (2d. ed. 1988).

18. Bradwell, 83 U.S. at 141 (Bradley, J., concurring).

19. Id. at 140 .

20. 88 U.S. 162 (21 Wall.) (1874).

21. Id. at 165 .

22. U.S. CONST. amend. XIX. 
theory that equal rights in voting implicitly banned sex discrimination in jury service; indeed, women could constitutionally be excluded from jury service even if states chose jurors from the very election rolls that the Nineteenth Amendment required the states to extend to both sexes. ${ }^{23}$ And as late as 1948, the Court upheld a Michigan law forbidding a woman to be licensed as a bartender unless she was the "wife or daughter of the male owner" of a bar. ${ }^{24}$

The Nineteenth Amendment's broader effect on constitutional law was limited to its role, in the era of Lochner v. New York, ${ }^{25}$ of defeating short-lived attempts to impose special occupational safety and hours regulations on establishments employing women. Within a few years of ratification, the Supreme Court was willing to point to the amendment to state that, since "[i]n view of the great-not to say revolutionary-changes which have taken place ... in the contractual, political, and civil status of women, culminating in the Nineteenth Amendment,"26 "the ancient inequality of the sexes, otherwise than physical... has continued 'with diminishing intensity," 27 coming "almost, if not quite, to the vanishing point,"28 grounds for differential enforcement of liberty of contract no longer existed. ${ }^{29}$ But outside of freedom to contract, and to vote, the Court found the Nineteenth Amendment to be of little import.

While the Reconstruction amendments separately guaranteed equal protection in the Fourteenth Amendment and banned race discrimination in voting in the Fifteenth, suggesting that the content of racial equality was

23. See, e.g., State v. Kelley, 229 P. 659 (Idaho 1924); People ex. rel. Fyfe v. Barnette, 150 N.E. 290 (11l. 1925); Commonwealth v. Wlosky, 177 N.E. 656 (Mass. 193I); State v. Mittle, 113 S.E. 335 (S.C. 1922). These and other state cases are discussed in Jennifer K. Brown, Note, The Nineteenth Amendment and Women's Equality, 102 YALE L.J. 2175, 2194-2201 (1993).

The law's tolerance for discrimination against women jurors, which extended at least through Hoyt v. Florida, 368 U.S. 57 (1961) (upholding a Florida statute under which married women were automatically exempted from the jury-service rolls unless they specifically requested to be placed on the jury-service list), is a particularly striking example of the pre-Reed view that the Equal Protection Clause did not address gender discrimination. As early as 1879 , the Supreme Court had struck down a West Virginia statute prohibiting Blacks from serving on juries. Strauder v. West Virginia, 100 U.S. 303 (1879). While the Court secured rights for Black jurors and Black defendants, it declined to extend this logic to women:

We do not say that within the limits from which it is not excluded by the amendment a State may not prescribe the qualifications of its jurors, and in so doing make discrimimations. It may confine the selection to males, to freeholders, to citizens, to persons within certaim ages, or to persons having educational qualifications. We do not believe the Fourteenth Amendment was ever intended to prohibit this.

Id. at 310 .

24. Goesaert v. Cleary, 335 U.S. 464,465 (1948).

25. 198 U.S. 45 (1905).

26. Adkins v. Children's Hosp., 261 U.S. 525, 553 (1923).

27. Id. (quoting Muller v. Oregon, 208 U.S. 412, 421 (1908)).

28. Id.

29. Id. (suggesting, however, that "physical differences must be recognized in appropriate cases"). 
not limited to equal access to the voting booth, no Amendment extends beyond equal protection of the franchise on the basis of sex. To be sure, the Equal Rights Amendment, debated in successive Congresses since $1923^{30}$ and proposed by both houses in 1971-72, would have provided that "[e]quality of rights under the law shall not be denied or abridged by the United States or by any State on account of sex."31 But it had the ignominy of being one of only six amendment proposals in our history to have passed Congress but failed ratification im the states, ${ }^{32}$ falling three states short of the thirty-eight needed before its extended deadline lapsed in $1982 .{ }^{33}$

\section{II}

\section{InFERRINg Sex Equality From Equal Protection}

In the absence of gender-specific constitutional text, the story of constitutionalizing American wonien's equality is a story of creative interpretation of the Equal Protection Clause and of advocates' bravado. Led with inventiveness and strategic brilliance by now-Justice Ruth Bader Ginsburg, ${ }^{34}$ litigating as a founding director of the American Civil Liberties Union Women's Rights Project, ${ }^{35}$ women's rights advocates persuaded the Court to read guarantees of sex equality into the Equal Protection Clause by analogizing sex discrimination to race discrimination. The story is familiar but nonetheless still striking in retrospect.

In 1971, Reed $v$. Reed held it irrational and thus unconstitutional under the Equal Protection Clause for the state of Idaho to prefer "males to females" as estate administrators when the degree of relationship to the decedent was otherwise a tie. ${ }^{36}$ The decision enabled Sally Reed, as against

30. For a summary of early proposals for constitutional amendments on women's equality, see John R. Vile, Encyclopedia of Constitutional Amendments, Proposed Amendments, and AMENDING Issues, 1789-1995, at 119 (1996).

31. H.R.J. Res. 208, 92d Cong., 86 Stat. 1523 (1972).

32. 5 Ronald D. Rotunda \& John E. NowaK, Treatise on Constitutional LAW: SubSTANCE AND PRocedure 375-78 (1999) (listing failed amendments).

33. See VILE, supra note 30, at 119; see also Martha Craig Daughtrey, Women and the Constitution: Where We Are at the End of the Century, 75 N.Y.U. L. REv. 1, 2-3 (2000).

34. For a list of the Supreme Court cases Justice Ginsburg participated in as an attorney, see Ruth Bader Ginsburg, The Progression of Women in the Law, 28 VAL. U. L. Rev. 1161, 1181-82 (1994).

35. See generally Ruth B. Cowan, Women's Rights Through Litigation: An Examination of the American Civil Liberties Union Women's Rights Project, 1971-76, 8 CoLUM. HuM. RTS. L. Rev. 373 (1976). See also KERBER, supra note 10, at 202-04 (describing Ginsburg's role in formulating the early goals of the Woinen's Rights Project).

For Justice Ginsburg's own description of several cases she was involved in, see Ruth Bader Ginsburg \& Barbara Flagg, Some Reflections on the Feminist Thought of the 1970s, 1989 U. CHI. LeGal F. 9, 11, 14-17; Ruth Bader Ginsburg, Introduction to Women and the Law: Facing the Millennium, 32 IND. L. REv. 1161 (1999); Ruth Bader Ginsburg, Constitutional Adjudication in the United States as a Means of Advancing the Equal Stature of Men and Women Under the Law, 26 Hofstra L. Rev. 263, 266-68 (1997) [hereinafter Ginsburg, Constitutional Adjudication].

36. 404 U.S. 71, 74 (1971). 
her separated husband, to administer the estate of their teenage son who had committed suicide with his father's gun. ${ }^{37}$

In 1973, in Frontiero v. Richardson, Ginsburg won a case on behalf of a servicewoman challenging a rule that presumed wives to be dependent on their military husbands for purposes of obtaining housing and medical benefits, but required husbands to prove dependency on their military wives. ${ }^{38}$ Ginsburg's brief dryly described prior cases that had permitted states to exclude women from voting, jury service, and membership in either kind of bar as "[p]recedent in need of re-evaluation." won the case, but her argument that the Court should adopt strict scrutiny, or a strong presumption against sex discrimination in the absence of a compelling justification, ${ }^{40}$ won the votes of only four Justices, led by Justice Brennan. ${ }^{41}$

Challenging similar presumptions of female dependency in cases brought by men aggrieved by procedural hurdles in benefits cases, Ginsburg obtained similar results: Weinberger $v$. Wiesenfeld ${ }^{42}$ struck down another two-tiered system under which social security survivor benefits were presumptively accorded to widowed mothers but were available to widowed fathers only upon proof of dependency. The case was brought by a widower seeking to raise his infant son after his wife died in childbirth. ${ }^{43}$ In the course of litigating Wiesenfeld, Ginsburg lowered her sights from strict scrutiny, which would have operated as a strong presumption against sex-discriminatory laws, to intermediate scrutiny, under which a merely

37. See Ginsburg, Constitutional Adjudication, supra note 35, at 267; Allen Derr, Cases of the Century: Reed v. Reed, Advocate (Idaho), Jan. 2001, at 20.

38. Frontiero v. Richardson, 411 U.S. 677 (1973).

39. Brief of American Civil Liberties Union as Amicus Curiae at 34, Frontiero v. Richardson, 411 U.S. 677 (1973) (No. 71-1694) thereinafter ACLU Amicus Curiae Brief].

40. See id. at 24 (arguing that "the court below should have subjected [the law] to close scrutiny, identifying sex as a 'suspect' criterion for legislative distinctions"); $i d$. at 27-28 ("I]t is presumptively inpermissible to distinguish on the basis of congenital and unalterable traits of birth over which the individual has no control.... Such conditions include not only race, lineage and alienage... but include as well the sex of the individual."); id. at 43-44 ("Amicus urges that designation of sex as a suspect classification is overdue."); id. at 57-59 (arguing that the classification should be scrutinized for "compelling state interest").

41. See Frontiero, 411 U.S. at 678,688 (Brennan, J., joined by Douglas, White, and Marshall, JJ.) ("[W]e can only conclude that classifications based upon sex, like classifications based upon race, alienage, or national origin, are inherently suspect, and inust therefore be subjected to strict judicial scrutiny."). Justice Stewart concurred in the judgment, without inuch explanation. Id. at 691 (Stewart, J., concurring in the judgment). Three other Justices concurred in the result, but refused to "characterize sex as a suspect classification," preferring instead to defer to "state legislatures, functioning within the traditional democratic process, ... debating the proposed [Equal Rights] Amendment." Id. at 691-92 (Powell, J., joined by Burger, C.J., and Blackmun, J.). Justice Rehnquist dissented. Id. at 691 (Rehnquist, J., dissenting).

42. 420 U.S. 636 (1975).

43. The son eventually went to law school. See Ginsburg, Constitutional Adjudication, supra note 35, at 268. Califano v. Goldfarb, 430 U.S. 199 (1977), applied the same logic to social security spousal benefits. 
important or significant governmental interest might be sufficient to sustain a sex-discriminatory law. ${ }^{44}$ The Court adopted just that standard one year later in Craig $v$. Boren, invalidating a state law that permitted women to buy near-beer at age eighteen, but required men to wait until age twentyone. $^{45}$

In 1996, now as a Justice, Ginsburg announced in United States $v$. Virginia that Virginia would have to admit women to the formerly all-male Virginia Military Institute ("VMI"), having failed to provide the requisite "exceedingly persuasive justification" 46 for a scheme placing fenale would-be cadets in a separate but decidedly unequal girls' school lacking VMI's funding, prestige, and adversative method. Overbroad generalizations about talents and capacities based on sex were held not merely unpersuasive as a justification, but impermissible. In addition, Virginia's claim to provide a diversity of educational opportunities via single-sex schooling, while possibly sufficient had it been the actual reason for sexual segregation ex ante, was not sufficient when concocted ex post. ${ }^{47}$

Lacking explicit constitutional authority, the Court's path to Virginia's result was difficult and tortuous, ${ }^{48}$ and more cases concerning

44. See Brief for Appellee at 23, Weinberger v. Weisenfeld, 420 U.S. 636 (1975) (No. 73-1892) (implying that " $[r]$ ectifying the effects of past discrimination against women (or historically disadvantaged minorities) is a laudable legislative objective" that might support a gender classification, but arguing that "a court must assure itself that the classification in fact works to alleviate past discrimination, and does not perpetuate practices responsible for that discrimination"). But cf. id. at 2630 (arguing that mere cost savings is not a legislative goal important enough to support gender classifications).

45. See 429 U.S. 190, 197 (1976) ("To withstand constikutional challenge, previous cases establish that classifications by gender must serve important governmental objectives and must be substantially related to achievement of those objectives."). Ginsburg had previously argued for intermediate tests as an alternative to her preferred strict test in her brief in Frontiero v. Richardson. See ACLU Amicus Curiae Brief, supra note 39, at 59-60 ("If the Court concludes that sex is not a suspect classification, or determines not to reach that question, amicus urges application of an intermediate test" imder which "[r] egulations that disadvantaged women should be 'closely scrntinized" with the burden on the proponent of the discriminatory action to establish that the sex-based classification is 'necessary to accomplishment of legitimate [legislative] objectives."') (citations omitted).

46. 518 U.S. 515, 531 (1996) (citing Miss. Univ. for Women v. Hogan, 458 U.S. 718, 724 (1982)). The term "exceedingly persuasive justification" can be traced back to Personnel Administrator of Massachusetts v. Feeney, 442 U.S. 256, 273 (1979), which, en route to denying a wounan's challenge to a veterans' preference law clearly benefiting males, had nevertheless stated that "any state law overtly or covertly designed to prefer males over feinales in public employment would require an exceedingly persuasive justification to withstand a constitutional challenge ...."

47. See Virginia, 518 U.S. at 533.

48. That path also left uncertain precedent, as illustrated by Ngzyen v. INS., 533 U.S. 53 (2001), which, in upholding a preference for female over male citizens in the ability to confer citizenship upon their children born out of wedlock abroad, read the "exceedingly persuasive" test as but a synonym for ordinary intermediate scrutiny. See id. at 70 (citing Hogan, 458 U.S. at 724). Justice O'Connor's Ngryen dissent argued that the inajority had backslid from Virginia and its predecessors, in accepting hypothetical rationales as justification for the classification at issue, and depending on overbroad sexual generalizations. Id. at 78 (O'Connor, J., dissenting) ("The Court recites the governing substantive standard for heightened scrutiny of sex-based classifications, but departs from the guidance of our 
sex equality were brought on behalf of men than of women. ${ }^{49}$ The lack of explicit constitutional text mandating women's equality forced each evolving statement of the doctrine to reveal its dependency on precedent: at its base, the argument for invalidating sex discrimination required analogizing it to race discrimination. ${ }^{50}$ Equal protection law was the creature of slavery, the central American equality issue. But in adapting the law of race discrimination for sex discrimination, the Court faced certam analogical crises.

On the one hand, sex is like race: it is a visible and generally immutable characteristic that has been used to stereotype and classify, without regard to individual merit, in realms involving public benefits and private social ordering. Women, like African Americans, have been subject to formal legal disadvantages with respect to voting, jury service, occupational licenses, property ownership, and the like. ${ }^{51}$ Members of both groups have been subject to social prejudice and stigma when they exceeded the boundaries of the roles laid down for them.

On the other hand, sex differs importantly from race in some respects. If courts ought, in the famous words of Justice Stone's Carolene Products footnote, to show special solicitude for "discrete and insular minorities,"52 it might well be objected that, like the Holy Roman Empire-which was neither holy, Roman, nor an empire-women are neither discrete, insular, nor a minority. Women are not discrete and insular because, whatever sexual segregation there has been in public life, "[t]he degree of contact between men and women could hardly be greater," as Dean John Hart Ely once put it, in private life. ${ }^{53}$ Women, unlike racial minorities, ${ }^{54}$ have not

precedents concerning such classifications in several ways. ... For example, the majority hypothesizes about the interests served by the statute and fails adequately to inquire into the actual purposes...."); id. at 86-87 (describing majority's reasoning as "rest[imgl only on an overbroad generalization.... There is no reason, other than stereotype, to say that fathers who are present at birth lack an opportunity for a relationship on similar terms").

49. See infra note 101 .

50. See, e.g., Frontiero, 411 U.S. at 685 ("[T]hroughout much of the 19th century the position of women in our society was, in many respects, comparable to that of blacks under the pre-Civil War slave codes.") (citations omitted).

51. See supra note 10.

52. United States v. Carolene Prod. Co., 304 U.S. 144, 152 n.4 (1938).

53. John HaRT Ely, Democracy and Distrust: A Theory of Judicial Review 164 (1980). This point only goes so far. Integration by household and connection by blood relation does not by any means guarantee equality; this much is clear from the example of antebellum slaveholding. Ely notes, in addition, that women are not "'in the closet' as homosexuals historically have been." Id.

54. See Derrick Bell, Race, Racism and American Law 369 (4th ed. 2000) ("[H]ousing in this country has remained largely segregated, and many areas have become more segregated.... As Joan Magagna, acting chief of the Housing and Civil Enforcement Section of the Justice Department has said[,] 'It is quite unusual to live next door to someone of a different color."”) (citations omitted). See also Haya El Nasser, Hispanic Growth Reveals Isolation: Trend Might Take Decades to Reverse, USA TODAY, Mar. 26, 2001, at 1A. ("[T]he average non-Hispanic White lives in a neighborhood that is only 6.3 percent Hispanic ...."). 
experienced entrenched residential segregation, but integrated with men as wives, lovers, sisters and daughters. ${ }^{55}$ This might be thought to yield not only sympathy but also interdependence by which the economic well-being of men is directly tied to that of women. One might predict, as a result, that women's aspirations would be more visible in the polity as a whole; even men not sympathetic to broad femimist goals might be expected to support the aspirations of women they live with, ${ }^{56}$ especially given the community of interest in two-wage-earner households. Moreover, because the economic disadvantages caused by sexism are not inherited in the same way as disadvantages caused by racism, economic effects of sexism might be less self-perpetuating than economic effects of racism, so long as systems of inheritance are sufficiently neutral. Perhaps only those women who seek to enter traditionally male roles are discrete and insular, as they are set apart not only from men, but also from other women. ${ }^{57}$

Nor are women a minority. Women are a numerical majority both demographically ${ }^{58}$ and, after the Nimeteenth Amendment, electorally, ${ }^{59}$ and

55. For instance, in 1998, 59.3\% of women over age eighteen were married (to males), and $58.6 \%$ of men over age eighteen were married (to females), numbers that do not include the many formerly married individuals now widowed or divorced. U.S. Census Bureau, STATISTICAL ABSTRACT OF THE UNITEd STATES 57 tbl. 62 (1999). In contrast, while the rate of interracial households has been increasing, only $5 \%$ of marriages are interracial. Tony Pugh, Mixed Marriages on the Rise in U.S.: Racial, Ethnic Barriers Abating as Country Becomes More Diverse, Houston Chron., Mar. 25, 2001, at A12.

56. Compare then-Judge Ginsburg's comment that "[t]he Justices received relevant education as the 1970s wore on, publicly from the press and the briefs filed in court; privately, I suspect, from the aspirations of women, particularly the daughters, in their own families and communities." Ginsburg \& Flagg, supra note 35, at 18 .

57. Such a view is expressed in Joint Reply Brief of Appellants and American Civil Liberties Union Amicus Curiae at 13, Frontiero v. Richardson, 411 U.S. 677 (1973) (No. 71-1694):

Worse than being "discrete and insular," which for other minority groups at least has the advantage of fostering political organizing, women are separated from each other.... For women who do not want to exercise options that do not fit within stereotypical notions of what is proper for a feinale, woinen who do not want to be "protected" but do want to develop their individual potential without artificial constraints, classifications reinforcing traditional male-female roles are hardly "bemign."

But, as John Ely said, the point loses urgency as high-achieving women become less exceptional: "Given such open discussion of the traditional stereotypes, the claim that the numerical majority is being 'dominated,' that women are in effect 'slaves' who have no realistic choice but to assimilate the stereotypes, is one it has become impossible to maintam except at the most inflated rhatorical level." ELY, supra note 53, at 166.

58. As of 1998, there were over six million more woinen than men residing in the United States; women comprised $51.1 \%$ of the population. U.S. Census Bureau, Statistical ABstract of the UNITED STATES 16 tbl. 16 (1999).

59. Women not only constitute a majority of the voting-age population, but also have tended to register and tum out to the polls in higher percentages than men have. See U.S. CENSUS BurEau, Statistical Abstract of the United States 300 tbl. 487 (1999). In the 2000 presidential election, $52 \%$ of voters were female. See Marjorie Connelly, Who Voted: A Portrait of American Politics, 19762000 , N.Y. TMmes, Nov. 12, 2000, at D4. 
could exercise majority voting power if they were to vote as a bloc. ${ }^{60}$ In contrast, there is not a single state in which Blacks or Latinos constitute a majority of residents of voting age. ${ }^{61}$

Moreover, race and sex discrimination have differed historically in severity and motivation. Even if, as Justice Brennan recognized in Frontiero, the "pedestal" on which woinen have been placed can become a "cage," 62 no one ever confused a pedestal with an auction block upon which human beings were bought and sold as chattel. The history of separate spheres for men and women, with the division of labor it enforced, was rooted more in "romantic paternalism"63 than in the fear and loathing that characterized the era of American apartheid from Plessy v. Ferguson ${ }^{64}$ to Brown v. Board of Education. "65] "[The perception of racial classification as inherently odious stems from a lengthy and tragic history that gender-based classifications do not share."

Finally, while race has been deemed more a social than a biological construct, ${ }^{67}$ women alone can gestate and bear children. This irreducible biological difference between men and women has no analogue for race. Even the Virginia decision left room to take account of such differences: "Supposed 'inherent differences' are no longer accepted as a ground for race or national origin classifications. Physical differences between men and women, however, are enduring: '[T]he two sexes are not

60. For example, in the 2000 Presidential election $\mathrm{Al}$ Gore received $54 \%$ of women's votes and $42 \%$ of men's. Connelly, supra note 59, at D4. If no men had voted in the hotly contested 2000 election, Gore would have won thirty-one states and 370 electoral votes, chad or no chad. Center For Policy Alternatives Releases Post-Election Analysis: Does "W" Really Stand for Women?, U.S. NEWSWIRE, Nov. 10, 2000.

61. See U.S. Census Bureau, Statistical Abstract of the United States 302 tbl. 490 (1999). This is true even in California where, although non-Hispanic Whites no longer comprise an absolute majority, they nevertheless remain larger than any other ethnic group. See William Booth, California's Ethnic Diversity Grows: State Has the Most Multiracial People, WASH. Post. Mar. 30, 2001, at A3; Maria L. LaGanga \& Shawn Hubler, California Grows to 33.9 Million, Reflecting Increased Diversity, L.A. TIMEs, Mar. 30, 2001, at Al.

62. 411 U.S. at 684 (plurality opinion).

63. Id.

64. 163 U.S. 537 (1896).

65. 347 U.S. 483 (1954).

66. Regents of Univ. of Calif. v. Bakke, 438 U.S. 265, 303 (1978) (opinion of Powell, J.).

67. The Court has observed:

The particular traits which have generally been chosen to characterize races have been criticized as having little biological significance. It has been found that differences between individuals of the same race are often greater than the differences between the "average" individuals of different races. These observations and others have led some, but not all, scientists to conclude that racial classifications are for the most part sociopolitical, rather than biological, in nature.

Saint Francis Coll. v. Al-Khazraji, 481 U.S. 604, 610 (1987) (permitting invocation of civil rights statutes by Whites). 
fungible; a community made up exclusively of one [sex] is different from a community composed of both."

Race and sex discrimination are therefore imperfectly analogous. When faced with such analogical crises, the Supreme Court often splits the difference by striking down some but not all types of challenged law (recall, for example, the Court's treatment of First Amendment challenges to the regulation of campaign finance ${ }^{69}$ and commercial speech ${ }^{70}$ ). In applying the Equal Protection Clause to sex discrimination, the Court has used a threshold "real differences" test and intermediate as opposed to strict scrutiny to express its ambivalence about the racial analogy. ${ }^{71}$ Where the Court finds a law predicated upon "real differences" between men and women, it requires only mimimum rationality. For example, a government decision to exclude pregnancy froin publicly funded medical benefits was infamously deemed not sex discrimination but a distinction between "pregnant ... and non-pregnant persons"; 72 and a statutory rape law protecting underage girls but not boys was held to refiect merely a natural asymmetry: the heavy burdens of possible pregnancy would deter girls from underage sex, but

68. United States v. Virginia, 518 U.S. 515, 533 (1996) (citations omitted) (alterations in original). Whether biological differences entail social differences between the sexes is controversial enough to have inspired at least one Justice to give contradictory accounts. Compare J.E.B. v. Alabama ex rel. T.B., 511 U.S. 127, 156 (1994) (Rehnquist, C.J., dissenting) (arguing for the need for sex-based peremptory challenges because, "[t]he two sexes differ, both biologically and, to a diminishing extent, in experience. It is not nierely 'stereotyping' to say that these differences nuay produce a difference in outlook which is brought to the jury roonl. Accordingly, use of pereniptory challenges on the basis of sex is generally not the sort of derogatory and invidious act which pereniptory challenges directed at black jurons inay be"), with Taylor v. Louisiana, 419 U.S. 522, $542-43$ (1975) (Rehnquist, J., dissenting) (objecting that the majority's suggestion of "'a flavor, a distinct quality,' which allegedly is lost if either sex is cxcluded" from a jury "smacks more of mysticism than of law").

69. See Buckley v. Valeo, 424 U.S. 1 (1976) (per curiam) (striking down caps on campaign expenditures, independent expenditures, and personal expenditures from candidates' own funds, but upholding individual contribution linits, public financing, and mandatory reporting provisions as measures to prevent "corruption" or "the appearance of corruption"). Buckley steered between two poles of the debate, neither trcating all restrictions on political money as restrictions on speecb to be invalidated unless justified by enpirically powerful deinonstrations that they avert serious harm, nor deferring to all restrictions on political money as mere market regulations.

70. The Court requires less justification for regulation of advertising than of other speech. See, for example, Board of Trustees of State University of New York v. Fox, 492 U.S. 469, 480 (1989), in which the Court declared:

What our decisions require is a "'fit' between the legislature's ends and the means chosen...,"-a flt that is not necessarily perfect, but reasonable; that represents not necessarily the single best disposition but one whose scope is "in proportion to the interest served;" that employs not necessarily the least restrictive means but... a ineans narrowly tailored to achieve the desired objective.

See also Central Hudson Gas \& Elec. Corp. v. Pub. Serv. Comm'n, 447 U.S. 57 (1980) (citations ounitted) (approving of regulation that "directly advances" a "substantial" government interest by ineans that are "not more extensive than necessary").

71. Cf. Virginia, 518 U.S. at 568 (Scalia, J., dissenting) ("We have no established criterion for [when to apply] 'intermediate scrutiny' but essentially apply it when it seens like a good idea to load the dice.").

72. Geduldig v. Aiello, 417 U.S. 484,496 n.20 (1974). 
boys needed the added disincentive of the criminal law. ${ }^{73}$ Separate but equal, while forbidden in matters of race, ${ }^{74}$ might sometimes be permitted with regard to gender - at a minimum for bathrooms ${ }^{75}$ and, as a tantalizing footnote in Virginia suggested, perhaps even for all-girls' schools. ${ }^{76}$ And where the Court does find sex discrimination, it may be upheld if closely tailored to an important government reason even if not essential to a compelling one, as required to uphold race discrimination. ${ }^{77}$ Laws selfconsciously and deliberately enacted to compensate for past discrimination against women, such as laws allowing women more years to prove their worth in an up-or-out naval officer promotion scheme, ${ }^{78}$ or counting fewer of women's low-wage years in calculating social security retirement payouts, ${ }^{79}$ might be upheld, even with fuzzier records of past official discrimination than the current Court requires to uphold ameliorative preferences on the basis of race. ${ }^{80}$

73. Michael M. v. Super. Ct. of Sonoma County, 450 U.S. 464, 473 (1981) ("Because virtually all of the significant harmful and inescapably identifiable consequences of teenage pregnancy fall on the young female, a legislature acts well within its authority when it elects to punish only the participant who, by nature, suffers few of the consequences of his conduct."). Under the statute's definition of statutory rape, "only females [could] be victims, and only males [could] violate the section." Id. at 467 (citing Michael M. v. Superior Court of Sonoma County, 601 P.2d 572, 574 (Cal. 1979)).

74. See Brown v. Bd. of Educ., 347 U.S. 483, 495 (1954).

75. And for certain other imtimate spaces. See, e.g., Virginia, 518 U.S. at 550 n.19 ("Admitting women to VMI would undoubtedly require alterations necessary to afford members of each sex privacy from the other sex in living arrangements ....").

76. The Court observed:

Several amici have urged that diversity in educational opportunities is an altogether appropriate governmental pursuit and that single-sex schools can contribute importantly to such diversity. Indeed, it is the mission of some single-sex schools "to dissipate, rather than perpetuate, traditional gender classifications." We do not question the Commonwealth's prerogative evenhandedly to support diverse educational opportunities. We address specifically and only an educational opportunity recognized by the District Court and the Court of Appeals as "unique," an opportunity available only at Virginia's premier military institute, the Commonwealth's sole single-sex public university or college.

Id. at $533 \mathrm{n} .7$ (citations omitted).

77. Compare Craig v. Boren, 429 U.S. 190 (1976) (applying intermediate scrutiny to sex classification in drinking ages), with Korematsu v. United States, 323 U.S. 214 (1944) (applying strict scrutiny to Japanese internment during World War II).

78. See Schlesinger v. Ballard, 419 U.S. 498 (1975) (upholding preference as compensation for female officers' career disadvantages).

79. See Califano v. Webster, 430 U.S. 313 (1977) (upholding preference to compensate for presumed wage discrimination).

80. As a result of the lower level of scrutimy accorded to sex discrimination, women, though only recently protected under equal protection in the first place, are spared the difficult task of satisfymg strict restrictions on race-based affirmative action under Adarand Constructors, Inc. v. Pena, 515 U.S. 200, 237 (1995). Pcrhaps paradoxically, "a lesser degree of doctrinal concern for gender-based problems produces a greater degree of doctrinal latitude for solving those problems ...." CatHARINE A. Mackinnon, Sex Equality 437 (2001). 


\section{III}

Five Axes of Choice in Drafting Original Constitutional Sex

\section{EQUALITY}

What choices would a hypothetical set of feminist drafters face if they were to constitutionalize women's equality from scratch? Suppose that the context were a society like modern American society, minus its racial history: an advanced industrial, democratic society with a legacy of legally and culturally enforced stereotyping of women as suited to the home and family rather than the market or war, but unconstrained by a central focus on a history of human bondage rooted in racism. What jurisprudential choices would face them im drafting a constitutional provision providing for women's equality with men? Such drafting would require choosing: (1) between a general provision favoring equality or a specific provision favoring sex equality, (2) between limiting classifications based on sex or protecting the class of women, (3) between reaching only state discrimination or reaching private discrimination as well, (4) between protecting women from discrimination or also guaranteemg affirnative rights to the material preconditions for equality, and (5) between setting forth only judicially enforceable or also broadly aspirational equality norms.

\section{A. Generality vs. Specificity}

The first choice, between generality and specificity, asks whether the Constitution should advert specifically to sex or women, or rather merely to general primciples of nondiscrimmation or equality. This is an old debate, analogous to that between legal rules and standards. For example, a rule might set a speed limit at sixty-five miles an hour; a standard might set forth the admonition to drive safely for the conditions on the road. The American Constitution consists mostly of open-ended, vague, broad standards: the First Amendment, for example, speaks of freedom of speech, not the freedom to burn flags or make political contributions or engage in erotic dancing in the nude. State constitutions are often far more detailed and speciflc, and for that reason less constitution-like. ${ }^{81}$

The choice between generality and specificity principally affects the jurisdictional or imstitutional allocation of discretion. A broad, vague standard leaves much more discretion for future interpreters and decisionmakers to decide what facts are relevant to the policy expressed, and to expand the scope of application beyond initially contemplated fact scenarios.

81. The California Constitution, for instance, contains precise restrictions on the use of motor

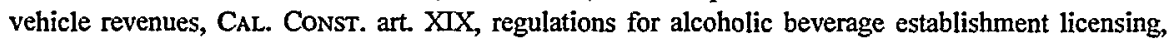
CAL. Const. art. XX, $\S 22$, property tax caps and assessinent rules, CAL. ConsT. art. XIII, $\S 1$, and tax exemptions for church parking lots, CAL. ConsT. art. XIII, § 4(d). See generally Kathleen M. Sullivan, Constitutional Constancy: Why Congress Should Cure Itself of Amendment Fever, 17 Cardozo L. REv. 691 (1996). 
Specificity is more directive and restraining, tymg future interpreters' and decisionmakers' hands. Historical imterpretation of the Equal Protection Clause illustrates the discretionary character of broad, vague, general standards: having pointedly excluded women suffragists at the outset, it has become the textual basis for enforcing women's equality today.

But note that the use of general equality standards defers to another day the question in what specific respects women should count as equal. Do women enjoy equal civil rights to property ownership and the capacity to sue; equal political rights to vote, serve on juries, or hold public office; or even equal rights against private actors by analogy to the Thirteenth Amendment's ban on slavery? No general equality standard can predetermine the answer.

In contrast, more specific provisions would particularize the classifications or the classes covered, or the privileges and immunities to which the ban on discrimination applies. As an example of a highly specific provision, consider Article I of the 1979 Umited Nations Convention on the Elimination of All Forms of Discrimination Against Women ("CEDAW"), ${ }^{82}$ which arose from the 1948 United Nations Universal Declaration of Human Rights. ${ }^{83}$ While the Declaration, like the Equal Protection Clause, is general ("All are equal before the law and are entitled without any discrimination to equal protection of the law"84), CEDAW, by contrast, is highly specific, defining discrimination against women as:

any distinction, exclusion or restriction made on the basis of sex which has the effect or purpose of impairing or nullifying the recognition, enjoyment or exercise by women, irrespective of their marital status, on a basis of equality of men and women, of human rights and fundamental freedoms in the political, economic, social, cultural, civil or any other field. ${ }^{85}$

Note that specificity does not entail narrowness; CEDAW specifies domains of women's rights that are quite broad.

Why might one specify that discrimination is forbidden against a class (women) or on the basis of a classification (sex) ${ }^{86}$ - as do many antidiscrimination statutes, ${ }^{87}$ the constitutions of twenty-one states, ${ }^{88}$ and as

82. Convention on the Elimination of All Forms of Discrimination Against Women, Dec. 18, 1979, 1249 U.N.T.S. 13 (entered into force Sept. 3, 1981) [hereinafter CEDAW].

83. Universal Declaration of Human Rights, G.A. Res. 217(AII), U.N. GAOR, 3d Sess., pt. 1, at 71, U.N. Doc. A/810 (1948) [hereinafter Declaration].

84. Id. at 73 (art. 7).

85. CEDAW, supra note 82, at 16 (art. 1).

86. For more on the distinction between classes and classifications, see infra Part III.B.

87. See, e.g., Equal Pay Act of 1963, 29 U.S.C. $\$ 206(d)$ (1998); Education Amendments of 1972 (Title LX), 20 U.S.C. $\$ 1681$ (1999); Civil Rights Act of 1964 (Title VII), 42 U.S.C. $\$ 2000$ e-2 (1994).

88. In 1998 there were nineteen states with constitutional language against sexual discrimination and twenty-one states with statutory provisions on the topic. See Robert L. MAddex, STATE Constitutions of the United States xxxvi-xli (1998). Since that time, at least Florida and Iowa 
mentioned earlier, constitutions of many other nations ${ }^{89}$ - rather than simply proscribe irrational discrimination in general? After all, any individual may be the victim of irrational discrimination, based on anything from appearance to astrological sign. A comprehensive response to the problem of discrimination would be simply to bar arbitrary adverse treatment, as, for example, common-carrier statutes do. ${ }^{90}$ One answer is that specificity may function as an administrative shorthand, expressing the principle not only that all irrational discrimination is bad but also that discrimination by race, sex, religion, and similar characteristics may be conclusively or nearly conclusively presumed irrational. ${ }^{11}$ This is a method of categorization familiar in other contexts, such as per se rules in antitrust law that express a conclusive presumption that price-fixing is unreasonably anticompetitive. ${ }^{92}$

The use of specific group-based criteria might also be understood to increase the efficiency of enforcement: all irrational discrimination is bad but discrimination based on sex, race, illegitimacy, alienage, or religion (or, for those willing to go further than the Supreme Court, discrimination based on sexual orientation or on disability ${ }^{93}$ ) is likely to be persistent rather than self-correcting, given the entrenchment of discriminatory social norms. ${ }^{94}$ Specificity helps isolate and focus legal resources upon those social groups that are likely to experience irrational discrimination more commonly than would be the case through the random exercise of idiosyncratic tastes. The most damaging discrimination may stem from widespread animus toward members of such groups, or from pervasive underestimation of their capabilities based on false stereotypes. Because such attitudes are socially systematic, victims of the discrimination cannot as easily escape through simple exit as can individuals faced with an adverse and isolated response from an idiosyncratic actor, such as a person unusually inimical to Scorpios. While the Scorpio can go across the street to another store where the merchant will be less hostile, discrimination against women and similar groups is likely to be particularly pervasive, persistent, and entrenched; thus it is not only resistant to self-correction

have added gender equality provisions to their state constitutions. See Debra Baker, The Fight Ain't Over, A.B.A. J., Aug. 1999, at 52, 55.

89. See supra notes 1-5 and accompanying text.

90. See, e.g., Communications Act of 1934 (Ch. II), 47 U.S.C. $\S \S 201,202$ (2001).

91. See Mark Kelman, Market Discrimination and Groups, 53 STAN. L. REv. 833, 859-66 (2001) (explaining "administrative" reasons why group membership might be rclevant to legal prohibitions).

92. See United States v. Trenton Potteries Co., 273 U.S. 392 (1927); see also Broad. Music, Inc. v. Columbia Broad. Sys., 441 U.S. 1 (1979); United States v. Socony-Vacuum Oil Co., 310 U.S. 150 (1940).

93. See Romer v. Evans, 517 U.S. 620 (1996) (applying rational-basis review to discrimination against gay men and lesbians); Cleburne v. Clebume Assisted Living Ctr., 473 U.S. 432 (1985) (holding that mental retardation is not a quasi-suspect classification).

94. See Kelman, supra note 91, at 863-65. 
through moral improvement, but also (because of its pervasiveness) resistant to correction through market-based competition.

On the other hand, a generalist alternative depends upon a clear baseline for appropriately equal treatment. In the conventions of the market, for example, discrimination means treating workers differently despite their equal marginal product, or treating customers differently despite their prospects of equal net revenues to the seller. ${ }^{95}$ But it is far more difficult to specify an appropriate baseline for equal treatment by government in regulation or redistribution. What net marginal amount of safety does the government owe each additional citizen in a jurisdiction? Which entirely optional welfare benefit out of a finite pool? Any attempt to surmount these problems leads to formulations that are vague or tautological. If a hypothetical Constitution, for example, barred use of any "consideration not relevant to the purpose of the government program," it would give little guidance about the criteria of irrelevance.

\section{B. Symmetry vs. Asymmetry}

Beyond the choice between generality and specificity, the hypothetical feminist constitution drafters would face a choice between symmetry and asymmetry. Should the ban on discrimination apply to forbidden classifications (such as sex, race, and sexual orientation) or to protected classes (such as women, African Americans, and gay men and lesbians)? This choice, too, echoes an old debate, this time between formal and substantive notions of equality. On the formal view, inequality consists of treatimg people differently across an irrelevant criterion; on the substantive view, the injury is subordinating one group to another. The first Justice Harlan offered both alternatives in his dissent from the separate-but-equal holding of Plessy v. Ferguson, ${ }^{96}$ stating that "[o]ur Constitution is color-blind"97 (that is, race is no legal ground for formally unequal treatment) and also that our Constitution does not permit a system of "caste" (that is, one race may not be made legally dominant over another).$^{99}$ If only caste matters, asymmetry is acceptable; as then-Justice Rehnquist once said in objecting to heightened scrutiny of laws nominally advantaging women, he was not

95. See id. at 841-42. Such a principle of nondiscrimination in the market would, for example, "preclude a dentist (as public accommodations provider) from refusing to treat a hearing-impaired patient, so long as his inability to communicate with the patient neither affected the price the patient would pay nor the cost of serving him." Id. at 844 . In the employinent context, the norm would "forbid[] an employer from refusing to hire a blind lawyer who can do the same work as a sighted one." Id.

96. 163 U.S. 537 (1896).

97. Id. at 559 (Harlan, J., dissenting).

98. Id.

99. Id. ("[1]n view of the constitution, in the eye of the law, there is in this country no superior, dominant, ruling class of citizens. There is no caste here. Our constitution is color-blind, and neither knows nor tolerates classes ainong citizens."). 
sure why men, who are socially and politically powerful, needed special protection by the courts. ${ }^{100}$ In contrast, protections aimed at impermissible classifications permit men to sue symmetrically with women, and Whites symmetrically with Blacks.

Most American antidiscrimination laws regulate classification, rather than classes. For example, the Equal Rights Amendment, which would have barred discrimination on the basis of sex, would have chosen classification, not class. For the most part, so does judicially crafted gender discrimination law under the Equal Protection Clause: indeed, male plaintiffs initiated two-thirds of the constitutional sex discrimination cases that have gone up to the Supreme Court, ${ }^{101}$ and the Virginia case is the rare recent counterexample of a case initiated on behalf of excluded women. Contrast this with the approach, for example, of the Ugandan Constitution, which provides that "women shall be accorded full and equal dignity of the person with inen," 102 or CEDAW, which, by the terms of its title, is both specific and aimed at the protection of the class of women rather than the classification of sex. Some laws split the difference, applying formally symmetrical criteria, but doing so out of special solicitude for the needs of specific subordinated groups; for example, the recently invalidated civil damages provisions of the federal Violence Against Women Act $^{103}$ created a cause of action against "gender motivated violence."104

Why choose classifications over classes? Is it merely to create an appearance of neutrality? Is it a strategic necessity to enlist the participation or acquiescence of the dominant group in an antidiscrimination regime?

100. See Craig v. Boren, 429 U.S. 190, 218-19 (1976) (Rehnquist, J., dissenting). In opposing heightened scrutiny of a drinking regulation that disfavored young men, Justiee Rehnquist argued:

Most obviously unavailable to support any kind of special scrutiny in this case is a history or pattern of past discrimination. ... There is no suggestion in the Court's opinion that inales in this age group are in any way peculiarly disadvantaged, subject to systeınatic discrininatory treatment, or otherwise in need of special solicitude from the courts.

Id.

101. See Judith A. Baer, Women's Rights and the Limits of Constitutional Doctrine, 44 W. Pol. Q. 821,823 tbl. 1 (1991) (indicatiug that men brought eighteen of the twenty-six constitutional cases decided by the Supreme Court between 1971 and 1984, during the development of the doctrine of unconstitutional sex discrimmation). And there have been notable wins by males pressing sex discrimination claims since then as well. For instance, when the Supreme Court extended the rule of Batson v. Kentucky, 476 U.S. 79 (1986) (prohibiting race-based peremptory challenges to jurors), to sex-based peremptory challenges, it did so at the behest of a male child-support-suit defendant objecting to the state's peremptory challenges against the men in his jury pool. See J.E.B. v. Alabama ex rel. T.B., 511 U.S. 127, 129 (1994). And in the recent case of Nguyen v. INS, 533 U.S. 53 (2001), the antidiscrimination right at issue was asserted by an immigrant arguing that immigration law had unfairly discrimmated against him in denying citizenship because his father, not his mother, was a U.S. citizen.

102. UGANDA CONST. art. 33 (1995 Constitution).

103. Pub. L. No. 103-322, 108 Stat. 1902 (Title IV) (1994).

104. 42 U.S.C. $\$ 13981$ (a) (1995). "[T] he term 'crime of violence motivated by gender' means a crime of violence committed because of gender or on the basis of gender, and due, at least im part, to an animus based on the victim's gender ...." 42 U.S.C. $\$ 13981$ (d)(1)(1995). 
Ruth Bader Ginsburg's answer, like Justice Brennan's in his famous pedestal-as-cage metaphor, ${ }^{105}$ was not merely strategic but substantive: dissolving sexual inequality, or empowering women, she argued, depends upon freeing both men and women from the gender roles in which historical socialization has trapped them. Giving women "preferences" that in fact exclude them from civic duties and hard jobs has helped to immure both woinen and men in separate spheres, impeding both men and women from pursuing opportunities that might make them exceptional to their gender. Women's freedom from stereotypes of fragility and dependence, on this view, requires men's freedom from stereotypes of aggressor and paterfainilias. Equality functions as a preference for fluid over fixed identity, and fluid identity depends upon disaggregating the biology of sex from the culture of gender. ${ }^{106}$ Under this approach, a man alleging sex discrimination is virtually representing women's best interests as well as his own. For example, Joe Hogan, challenging his exelusion from a womenonly public nursing school, helped women break out of stereotypically female occupations just as did the woinan who, as a high school student, initiated the United States' suit to open the Virginia Military Institute to women.

Even if a sex equality guarantee takes a basically symmetrical approach, it might nevertheless choose partial asymmetry by excepting from its prohibition affirmative or ameliorative action that aims to give preferences to the traditionally disadvantaged group. Again, such an exception might be more or less general or specific. The Canadian Constitution, for example, while providing that "every individual is equal before and under the law and has the right to equal protection and equal benefit of the law without discrimination based on ... sex, ${ }^{107}$ nevertheless states expressly that this provision "does not preclude any law, program or activity that has as its object the amelioration of conditions of disadvantaged... groups including those disadvantaged because of ... sex."108 American constitutional law, while containing no such formally specific text, as a practical matter upholds some preferences as forms of well-justified inequality. For example, the Court has declined to invalidate government schemes that allow women retirees to calculate social security payouts so as to compensate for their reeeipt of lower wages than inen during their working

105. See supra text accompanying note 62 .

106. See Mary Anne C. Case, Disaggregating Gender from Sex and Sexual Orientation: The Effeminate Man in the Law and Feminist Jurisprudence, 105 YALE LJ. 1, 9-13 (1995); see also Katherine M. Franke, The Central Mistake of Sex Discrimination Law: The Disagreggation of Sex from Gender, 144 U. PA. L. Rev. 1 (1995).

107. CAN. CoNST. (Constitution Act, 1982) pt. 1, (Canadian Charter of Rights and Freedoms), $\S 15(1)$.

108. Id. $\$ 15(1)$. 
years, ${ }^{109}$ as well as schemes that give woinen inore time for promotion in the Navy, thereby partially offsetting the effects of exclusion of women from combat-rated jobs. ${ }^{110}$

The question remains of what should count as acceptably ameliorative, a question that is particularly difficult when male litigants seek elimination of preferences for biological females. The Supreme Court has in effect approved affirmative action for women, but not affirmative action for ladies. As Ruth Bader Ginsburg once put the point, habits or traditional ways of thinking that lead to laws "grossly drawn solely by reference to sex" are unacceptable. ${ }^{111}$ Hence exceptional inen inust be admitted to Old Miss Nursing School ${ }^{112}$ and exceptional women to VMI, ${ }^{113}$ but a legislature that actually looks at empirical evidence of past economic discrimination against women still has "a corridor in which to move" by taking corrective or coinpensatory measures. ${ }^{114}$

1dentifying impermissible affirmative action for ladies-that is, smoking out preferences that "ratify and perpetuate invidious, archaic, and overbroad stereotypes about the relative abilities of men and women"115 -is not always an easy task. As Justice Ginsburg has cautioned, special pregnancy benefits or other special assistance with motherhood raise

a troubling concern: Patriarchal rules long sequestered women at home .... It is not always easy to separate rules that genuinely assist mothers and their children by facilitating a woman's pursuit of both paid work and parenting, from laws that operate to confine women to their traditional subordmate status .... ${ }^{116}$

Woinen professionals who take time off froin work to raise children still endure significant and often irreversible professional penalties. ${ }^{117}$ The hypothetical feminist Constitution drafters might therefore wish to be sparing in departing froin symmetry. By analogy, several women's advocacy groups filed briefs in the 1987 case of California Federal Savings \& Loan

109. Califano v. Webster, 430 U.S. 313,318 (1977) ("Congress... purposely enacted the more favorable treatment for female wage earners to compensate for past employment discrimimation against women.").

110. Schlesinger v. Ballard, 419 U.S. 498, 508 (1975) ("[T]he different treatment of men and women naval officers under $\$ \S 6382$ and 6401 reflects, not archaic and overbroad generalizations, but, instead, the demonstrable fact that male and female lime officers in the Navy are not similarly situated with respect to opportunities for professional service ....").

111. Ruth Bader Ginsburg, Remarks on Women Becoming Part of the Constitution, 6 Law \& INEQ. 17, 23 (1988).

112. See Miss. Umiv. for Women v. Hogan, 458 U.S. 718 (1982).

113. See United States v. Virginia, 518 U.S. 515 (1996).

114. Ruth Bader Ginsburg, Speaking in a Judicial Voice, 67 N.Y.U. L. Rev. 1185,1204 (1992).

115. J.E.B. v. Alabama ex. rel. T.B., 511 U.S. 127, 131 (1994).

116. Ruth Bader Ginsburg \& Deborah Jones Merritt, Affirmative Action: An International Human Rights Dialogue, 21 Cardozo L. Rev. 253, 258 (1999).

117. See generally Deborah L. Rhode, Speaking of Sex: The Denial of Gender Inequality (1997). 
Ass'n v. Guerra ${ }^{118}$ arguing that it was sex discrimination against men to grant paid pregnancy leaves to women but not disability leaves to other workers incapacitated for sinilar periods ${ }^{119}$-an argument the Court rejected. ${ }^{120}$

\section{Private Action vs. State Action}

The third methodological choice facing the hypothetical feminist drafters would be whether to apply the ban on discrimination only to public or also to private action. The Thirteenth Amendment is the only American constitutional provision that by its own terms applies to private action, ${ }^{121}$ although some have argued that the Fourteenth Amendment's Enforcement Clause was meant to einpower Congress to reach at least some private discrimination that the states were unlikely to remedy. ${ }^{122}$ In contrast, some other constitutions address private discrimination directly. The South African Constitution, for example, provides both that "the state may not

118. 479 U.S. 272 (1987).

119. See Brief Amici Curiae of the Nat'l Org. for Women, NOW Legal Def. \& Educ. Fund, Nat'1 Bar Ass'n Women Lawyers Div., Nat'l Women's Law Ctr., Women's Law Project, and Women's Legal Def. Fund in Support of Neither Party, Cal. Fed. Sav. \& Loan Ass'n v. Guerra, 479 U.S. 272 (1987) (No. 85-494); Brief of the ACLU, the League of Women Voters of the United States, the League of Women Voters of California, the Nat'l Women's Political Caucus, and the Coal Employment Inst., Amici Curiae, Cal. Fed. Sav. \& Loan Ass'n v. Guerra, 479 U.S. 272 (1987) (No. 85494).

120. Cal. Fed. Sav. \& Loan Ass'n, 479 U.S. at 280 (holding that Pregnancy Discrimination Act did not prohibit employment practices favoring pregnant women).

121. See Clyatt v. United States, 197 U.S. 207, 216 (1905) ("The prohibitions of the Fourteenth and Fifteenth Amendments are largely upon the acts of the States; but the Thirteenth Amendment names no party or authority, but simply forbids slavery and involuntary servitude...."); The Civil Rights Cases, 109 U.S. 3, 20 (1883) ("[T] The amendment is not a mere prohibition of State laws establishing or upholding slavery, but an absolute declaration that slavery or involuntary servitude shall not exist in any part of the United States."); id. at 23 (noting that the Thirteenth Amendment permits legislation "to eradicate all forms and incidents of slavery and involuntary servitude," and the Amendment has "direct and primary" effects "operating upon the acts of individuals, whether sanctioned by State legislation or not ...").

122. See United States v. Guest, 383 U.S. 745, 782 (1966) (Brennan, J., concurring in part and dissenting in part) ("A majority of the members of the Court expresses the view today that $\$ 5$ empowers Congress to enact laws punishing all conspiracies to interfere with the exercise of Fourteenth Amendment rights, whether or not state officers or others acting under color of state law are implicated in the conspiracy."); $i d$. at 761 (Clark, J., concurring) ("[T]here now can be no doubt that the specific language of $\S 5$ empowers the Congress to enact laws punishing all conspiracies-with or without state action-that interfere with Fourteenth Amendment rights.").

A majority on the current Court, however, rejects this view. See Bd. of Trs. of Univ. of Ala. v. Garrett, 531 U.S. 356, 368 (2001) ("Just as $\S 1$ of the Fourteenth Amendment applies only to actions committcd 'under color of state law,' Congress' $\S 5$ authority is appropriately exercised only im response to state transgressions."). 1nstead, the Court currently accepts the state action doctrine as found in the Civil Rights Cases, 109 U.S. 3, 11 ("It is State action of a particular character that is prohibited. Individual invasion of individual rights is not the subject matter of the [Fourteenth] [A]mendment."), and has rejected the idea that Guest indicated a wider power. See United States v. Morrison, 529 U.S. 598, 599, 624 (2000) (rejecting a reading of Guest to indicate congressional ability to reach private actors and reaffirming the "enduring vitality of the Civil Rights Cases"). 
unfairly discriminate directly or indirectly... on ground [of] sex,"123 and that "[n]o person may unfairly discriminate directly or indirectly against anyone on [such a ground]." 124

The American tradition of limiting constitutional constraints to government action is rooted in policies of both privacy and federalisin. Requiring the federal government and the states to treat women as the equals of men does not extend to the relationship between husband and wife, or employer and einployee. Constitutional immunity for a private sphere fosters normative pluralism; not all associations need to conform to the constitutional norms imposed on government. This vicw holds that while citizens enjoy robust rights against the state, intimate or expressive groups ought not to be conceived as miniature governments, microcosms of the democratic polity in which members are conceived as rightholders vis-à-vis their groups. The social institutions of liberal democracy need not be liberal or democratic all the way down; private associations should not all be colonized as outposts of public virtue. Maintaining safe harbors for private inequality promotes a kind of liberty or check on the homogenizing power of the state. However equalized men and women may be in the public sphere, at hoine woinen may still choose to be ladies. ${ }^{125}$

On the traditional view too, the state action requirement for federal constitutional claims preserves a default of decentralized government. It is principally the states with thcir plenary powers, not the federal government with its narrower delegated powers, that perform the task of regulating private life. ${ }^{126}$ This provides a geographical dimension to nornative pluralism; some states will regulate differently from others, and citizens may vote with their feet.

Antidiscrimination norms thus have been extcnded against private actors in the American system primcipally by statutory rather than constitutional prohibitions. Congress may require sex equality in employment, ${ }^{127}$ housing, ${ }^{128}$ education, ${ }^{129}$ or other activities significantly affecting interstate

123. S. AFr. Const. (Bill of Rights) $\$ 9$ (3) (1996).

124. S. AFr. ConSt. (Bill of Rights) $\$ 9$ (4) (1996).

125. Consider the comment by the Eagle Forum's Kathleen Teague, Hearing Before the House Comm. on the Armed Serv., 96th Cong., 2nd Sess. 105 (1980) (testimony of Kathleen Teague) ("Our young women have a constitutional right to be treated like American ladies, with the respect and the chivalry that ladies are accorded in the Judeo-Christian culture.") (quoted in KERBER, supra note 10, at 378 n.245).

126. See, e.g., United States v. Morrison, 529 U.S. 598, 619 n.8 (2000) ("[T]he principle that ' $[t]$ he Constitution created a Federal Government of limited powers,' while reserving a generalized police power to the States is deeply ingrained in our constitutional history.").

127. See Equal Pay Act of 1963, 29 U.S.C. $\$ 206$ (d) (1998); Civil Rights Act of 1964 (Title VII), 42 U.S.C. $\$ 2000 \mathrm{e}$ (1994).

128. See Fair Housing Act, 42 U.S.C. $\$ \S 3604,3605$ (1995).

129. See Education Amendments of 1972 (Title IX), 20 U.S.C. $\$ 1681$ (1999). 
commerce (even after United States $v$. Lopez). ${ }^{130}$ States may require sex equality in any sphere they wish, subject only to independent federal constitutional constraints such as the freedom of private expressive association. As such associated liberty is currently understood, the Boy Scouts or a hypothetical "Male Supremacist Society" might be free to exclude women despite a state law forbidding sex discrimination in public accommodations, ${ }^{131}$ but the Rotary Club ${ }^{132}$ or the Jaycees would not. ${ }^{133}$

Congress may also legislate to remedy state deprivations of equal protection, including selective failures to protect members of some groups from private interpersonal violence. For example, states need not have murder or battery laws at all, ${ }^{134}$ but if states do have such laws, then sheriffs may not look the other way when Blacks are lynched or women battered, and if they do engage im such selective omissions of protection of the law, then Congress may correct the state's omission through federal remedies (at least against the sheriffs or other state actors). ${ }^{135}$ In invalidating the federal civil damage remedy for violence against women, United States $v$.

130. United States v. Morrison, 529 U.S. 598, 610 (2000) ("Where economic activity substantially affects interstate commerce, legislation regulating that activity will be sustained."” (quoting United States v. Lopez, 514 U.S. 549, $560(1995)$ )).

131. This is the import of the Court's decisions in Hurley v. Irish-American Gay, Lesbian \& Bisexual Group of Boston, 515 U.S. 557 (1995) (holding that Massachusetts's use of its public accommodations laws to compel a parade to admit a gay and lesbian marching contingent violated the First Amendment), and Boy Scouts of America v. Dale, 530 U.S. 640 (2000) (holding that New Jersey's public accommodations laws could not constitutionally compel the Boy Scouts to permit the service of an otherwise exemplary gay scoutmaster in contradiction to the Boy Scouts' antigay interpretation of their governing statements). The Court suggested that civil rights statutes may compel an organization to accept unwanted members in its ranks only if such admission "would not materially interfere with the ideas that the organization sought to express." Id. at 657 . It is easy to see how the imclusion of women could directly burden the expressive message of a hypothetical Male Supremacist Society whose very ideology depended on the exclusion of women from male activities. The Boy Scouts would have a barder case, but could well prevail given the Court's deference last year to the Boy Scouts' own definition of their ideology. See id. at 651 ("[I]t is not the role of the courts to reject a group's expressed values because they disagree with those values or find them internally inconsistent.").

132. See Bd. of Dirs. of Rotary Int'l. v. Rotary Club, 481 U.S. 537 (1987) (rejecting free association claim invoked against law forbidding all-male clubs).

133. See Roberts v. U.S. Jaycees, 468 U.S. 609 (1984) (rejecting free association claim invoked against law forbidding all-male organizations).

134. See DeShaney v. Winnebago County. Soc. Servs. Dep't, 489 U.S. 189, 196 (1989) (" $[N]$ othing in the language of the Due Process Clause itself requires the State to protect the life, liberty, and property of its citizens against imvasion by private actors.").

135. See id. at $197 \mathrm{n.3}$ ("The State may not... selectively deny its protective services to certain disfavored minorities without violating the Equal Protection Clause."); see also, e.g., Neighborhood Action Coalition v. Canton, 882 F.2d 1012, 1017 (6th Cir. 1989) (finding basis for $\S 1983$ claim because "[t]he [Fourteenth] Amendment is violated when a police department fails to respond to calls from a neighborhood because of the racial make-up of the neighborhood"); Hynson v. Chester Legal Dep't, 864 F.2d 1026, 1031 (3d Cir. 1988) (setting forth requirements for women seeking to prove derrial of equal protection in police treatment of domestic violence); Catlette v. United States, 132 F.2d 902, 907 (4th Cir. 1943) (finding violation of federal civil rights law in deputy sheriff's failure to protect Jehovah's Witnesses from mob violence). 
Morrison $^{136}$ did not reject this principle; the Court simply did not find the remedy that Congress had provided against private perpetrators appropriately congruent and proportional to correcting the state omission. ${ }^{137}$ Similarly, states need not extend statutory protections against private discrimmation to all disadvantaged groups, but they may not remove the power to prohibit a particular type of discrimmation by "impos[ing] a special disability upon" a disfavored class alone, ${ }^{138}$ nor "encourag[ing] and significantly involv[ing] the State in private racial discrimination contrary to the Fourteenth Amendment."139

The argument for rejecting this statutory approach, and instead applying constitutional norns directly to private actors, might take either a general forn or a specific form addressing the situation of women. In its general form, the argument would hold that social equality is a necessary precondition to civic or political equality. The broader the private discrimination, the more enfeebled the exercise of civic or political participation on equal terins. Hence there is a need to contain private discrimination in order to make meaningful the bar on public discrimination. For example, in a society $\mathrm{m}$ which women are beaten at home or hassled on streets, few woinen might even bother to go to the polls to vote. And on this view, by not allowing a gay scoutmaster like Jim Dale to integrate the Boy Scouts and demonstrate gay competence to other Scouts, ${ }^{140}$ such private interactions help perpetuate gay exclusion from public institutions such as the U.S. Military.

The argument for applying constitutional norms specifically to private discrimination against women might note that women's physical and occupational confinement in the private sphere ${ }^{141}$ might well make state oinissions of enforcement against discriminatory harms particularly hard to prove, necessitating remedies that directly reach sex-discriminatory private

136. 529 U.S. $598(2000)$.

137. See id. at 625-26. For the view that the scope of Congress's remedial power over private action under the Fourteenth Amendment remains open to dispute, see Robert C. Post \& Reva B. Siegel, Equal Protection by Law: Federal Antidiscrimination Legislation After Morrison and Kimel, 110 YALE L.J. 441, 474-81 (2000).

138. Romer v. Evans, 517 U.S. 620,631 (1996) (imvalidating as an equal protection violation a state constitutional amendment barring enactment or enforcement of measures protecting gay men and lesbians from discrimination on the basis of their sexual orientation).

139. Reitman v. Mulkey, 387 U.S. 369, 376 (1967) (imvalidating a state constitutional amendment repealing state laws against private housing discrimination).

140. For the Supreme Court's ruling to the contrary, see Boy Scouts of America v. Dale, 530 U.S. $640(2000)$.

141. This argument might enphasize the entrenchment of violence against women in the private sphere of the home, which is largely immune from federal regulation. See Catharine A. MacKinnon, Comment, Disputing Male Sovereignty: On United States v. Morrison, 114 HaRv. L. REv. 135, 170 (2000) ("Morrison effectively defines the private as the location where effective redress for sex-based violence is unavailable...."). 
actors. ${ }^{142}$ On this view, for example, date rape at home does not easily fit the model of an impermissible conspiracy to deprive women of civil rights. Nor will state law enforcement authorities' differential treatment of rape, as compared with those batteries committed typically against men, necessarily appear to be a denial of equal protection, especially given that such selective indifference will rarely appear intentional, as equal protection doctrine requires. ${ }^{143}$

The counterargument favoring restriction of constitutional norms to public action might reply that federal law has not wholly abandoned women to the more "private" realm of the states. As Judge Patricia Wald has pointed out, federal law pervasively regulates relationships based on gender through a range of measures from tax and benefit schemes to the constitutionalization of rights of marriage, parenthood, and family formation. ${ }^{144}$ This observation might suggest that federal constitutional regulation of private sex discrimination is unnecessary so long as federal statutory regulation fills any void left by a patchwork of varying state responses. Nor, such a reply might stress, does protection of women's interests necessarily increase linearly with ever larger units of government. ${ }^{145}$ A strong view of state autonomy, which left the states free to prescribe substantive qualifications for voting, permitted western states to enfranchise women at a time well before the Nineteenth Amendment when the national consensus would not have permitted it. ${ }^{146}$ Likewise, local experimentation might

142. See id. at 172. MacKinnon noted:

Most violence against women is engaged in by non-state actors, people who are not public officials or acting with what is recognized as state authority. But they do act with the virtually total assurance that, as statistics confirm, their acts will be officially tolerated, they themselves will be officially invisible, and their victims will be officially silenced. That is, their acts will be kept private by exclusion froin public recognition or public redress. They are state-exempt acts.... Discriminatory abdication by public authority makes private acts public.

Id.

143. See Personnel Adm'r of Mass. v. Feeney, 442 U.S. 256, 273-74 (1979) (statimg that the requirement of discriminatory purpose for racial equal protection cases "appl[ies] with equal force to a case involving alleged gender discrimination"); Washington v. Davis, 426 U.S. 229 (1976) (holding that racially discriminatory intent is required to invalidate a government program as an equal protection violation, even if that program has racially disparate effects).

144. Patricia M. Wald, Some Unsolicited Advice to My Women Friends in Eastern Europe, 46 S.M.U. L. Rev. 557, 571-72 (1992); see also Judith Resnik, Gender Bias: From Classes to Courts, 45 Stan. L. Rev. 2195, 2200-01 (1993).

145. Contrast the view expressed by MacKinnon, supra note 141, at 174: "[M]en have the most freedom at home, and women gain correspondingly greater equality, hence freedom, the further away from home they go."

146. Note, in particular, Wyoming's enfranchisement of women in 1869, and Utah's enfranchisement of women in 1870, a full half-century before the Nimeteenth Amendment's ratification in 1920. See generally Carrie Hillyard, Comment, The History of Suffrage and Equal Rights Provisions in State Constitutions, 10 B.Y.U. J. PuB. L. 117, 120, 126 (1996). Other states followed: Colorado and 1daho (by 1886), Washington (1910), California (1911), Arizona, Kansas, and Oregon (1912), Illimois (1913), and Ohio, lndiana, Rhode Island, Nebraska, Michigan, New York, and North Dakota (1917). Id. at 131-32. 
mean civil unions for gay people in Vermont, ${ }^{147}$ while nationalization means the Defense of Marriage Act. ${ }^{148}$ This counterargument might continue by noting that despite the continuing gender bias that Congress considered in the Violence Against Women Act, ${ }^{149}$ the states today are hardly the backwaters with respect to women's rights that the southern states were with respect to race relations in the 1950s and 1960s. Rape laws have been widely reformed ${ }^{150}$ and sexual violence units have been instated in state law enforcement offices. ${ }^{151}$ Finally, the privacy preserved by state action doctrine might well be good for woinen; among other things, it allows reproductive autonomy and all-women colleges. It might be argued that such asymmetrical benefits would be protected under a properly substantive view of equality, but, in the absence of a consensus on substantive equality, it might well disadvantage women to constitutionalize too much of the private realin.

\section{Negative Rights vs. Positive Rights}

The fourth choice for the hypothetical feminist drafters would be one between negative and positive rights. Should women have only freedom from legal exclusion and discrimination, or also some guarantee of freedom to the material preconditions of the meaningful exercise of equal rights of citizenship? Such positive rights might include the right to work, mimimal subsistence, equal pay, literacy, reproductive control, health care, or education. The concern of those advocating positive rights, as distinguished from regulation of private discrimination, is less that women will be battered in the houne than that they will be tethered to it by an endless cycle of meals, diapers and laundry.

The American constitutional tradition generally provides for negative rights only, and excludes positive rights (with limited exceptions, such as the First Amendment's effectively compelled subsidy of speech in the public forum). ${ }^{152}$ American judges tend to view positive rights as

147. See Baker v. State, 744 A.2d 864, 886 (Vt. 1999) (finding a state constitutional obligation for Vermont "to extend to [same-sex couples] the common benefit, protection, and security that Vermont law provides opposite-sex married couples").

148. Defense of Marriage Act, Pub. L. No. 104-199, 110 Stat 2419 (1996) (defining "spouse" and "marriage" so as to exclude same sex partners and same sex civil unions, and exempting states from any Full Faith and Credit requirement to recognize other states' same-sex nnarriages).

149. See United Statcs v. Morrison, 529 U.S. 598, 619-20 (2000).

150. See generally Cassia Spohn \& Julie Horney, Rape Law Reform: A Grassroots REVOLUTION AND ITS IMPACT 21-27 (1992) (discussing major elements of rape law reform).

151. See U.S. Dep'T of Justice OfFice for Victims of Crime, New Directions from the Field: Victims' Rights AND Services FOR THE 21st CENTURy 48-55 (1998). In addition, "[in]ost states now mandate traming on doinestic violence for law enforcement, and the majority of state law enforcement academies offer training on domestic violence and sexual assault as part of the basic curriculum for recruits." $I d$. at 58.

152. See Hague v. ClO, 307 U.S. 496 (1939) (holding that the freedom of speech confers a prescriptive easement of access for speakers to public streets and parks). 
unenforceable; after all, judges lack the direct power of the fisc, and proclaimmg unenforceable rights might well dilute popular respect for other constitutional provisions. ${ }^{153}$

Other constitutional traditions, in contrast, do mclude positive rights. European judges from social democratic traditions often express surprise that American judges furnish extravagant protection to civil liberties such as speech, but not to socioeconomic liberties such as the provision of basic welfare. The United Nations Declaration of Human Rights sets forth social and economic rights as well as civil rights, providing that "[e]veryone is entitled to all the rights and freedoms set forth in this Declaration without distinction of any kind such as ... sex ...."154 The International Covenant on Economic, Social and Cultural Rights, signed by many nations in implementation of that Declaration provides that signatories shall ensure "just and favourable conditions of work," including "fair wages and equal remuneration for work of equal value without distinction of any kind, $\dot{m}$ particular women bemg guaranteed conditions of work not inferior to those enjoyed by men, with equal pay for equal work."155 And CEDAW contams an extensive list of affirmative commitments to ensure the "full development and advancement of women ... on a basis of equality with men"156 in education, ${ }^{157}$ reproductive hcalth advice and services, ${ }^{158} \mathrm{em}$ ployment, ${ }^{159}$ and even recreation. ${ }^{160}$

The American constitutional tradition treats such economic liberation as a matter of statutory grace, not constitutional right. Legislatures might choose to subsidize prenatal care, families with dependent children, or family planning advice, but need not do so. Negative freedom might be

153. For example, note that the Soviet Constitution at its downfall guaranteed a right to work. See U.S.S.R. CONST. art. 40 (1977).

154. Declaration, supra note 83, at 72 (art. 2).

155. International Covenant on Economic, Social and Cultural Rights, Dec. 16, 1966, 993 U.N.T.S. 3,6 .

156. CEDAW, supra note 82, at 16 (art. 3).

157. Id. at 17-18 (requiring not only equality for men and women, but also "[t]he reduction of female student drop-out rates and the organization of programmes for girls and women who have left school prematurely," (art. 10(f)), as well as "[t]he elimination of any stereotyped concept of the roles of men and women at all levels and in all forms of education by encouraging coeducation and other types of education which will help to achieve this aim and...the revision of textbooks and school programmes and the adaptation of teaching methods ..." (art. 10(c)).

158. Id. at 19 (art. 12) (requiring nations "to ensure, on a basis of equality of men and women, access to health care services... related to family planning" as wcll as "appropriate services in connexion with pregnancy, confinement and the post-natal period, granting free services where necessary, [and] adequate nutrition during pregnancy and lactation"); Id. at 18 (art. 10(h)) (requiring nations to ensure "access to specific educational information to help to ensure the health and well-being of families, including information and advice on family planning").

159. Id. at 18-19 (committing not only to the elimination of discrimmation, but also to "maternity leave with pay," (art. 11, §2(b)) and access to child-care facilities (art. 11, 2 (c)).

160. Id. at 19 (art. 13(c)) (addressing "[t]he right to participate in recreational activities, sports and all aspects of cultural life"); Id. at 18 (art. 10(g)) (requiring for both genders "[t]he same opportunities to participate actively in sports and physical education"). 
expected to generate economic advancement for women as a byproduct: Freed from the legalized constraints of preassigned gender roles, women might be expected to gain agency and reshape their lives, becoming more like men and less dependent upon them. Alternatively, women might fashion new practices in a new world that cannot even be predicted from the vantage point of the old. But the American Constitution does not set a minimum threshold for the material preconditions for full exercise of such negative freedom.

\section{E. Judicially Enforceable Standards vs. Hortatory Norms}

Finally, the hypothetical original drafters would face a choice between judicially enforceable standards and norms that are hortatory or aspirational. A strong culture of judicial review, it might be argued, depends upon judges' abilities to have their decrees enforced by the political branches, and thus constitutional provisions must be modest in scope, lest constitutional pronouncements prove empty because ignored.

Contrast this approach, which predommates in American constitutional law, with other documents that would include some aspirations seemingly incapable of direct enforcement. For example, Article 5 of CEDAW commits signatories to take all appropriate measures

to modify the social and cultural patterns of conduct of men and women, with a view to achieving the elimination of prejudices and customary and all other practices which are based on the idea of the inferiority or the superiority of either of the sexes or on stereotyped roles for men and women. ${ }^{161}$

Cultural liberation might be the anticipated end-state promoted by American equality norms, but CEDAW's text contrasts sharply with limited freedom from state discrimination provided for in the Equal Protection Clause. Moreover, such aspirational norms might raise conflicts with other constitutional liberties, such as freedoms of expression and association. Not surprisingly, the Umited States, which is not among the 165 nations that have ratified CEDAW, has expressed reservations about such hortatory provisions for just such reasons. ${ }^{162}$

The idea of constitutionalizing hortatory norms is so foreign to American constitutional law that it is difficult to understand what effect such provisions would have if included, or to whom they would be addressed-to legislators, executive officials, or private citizens and votes,

161. CEDAW, supra note 82, at 17 (art. 5 (a)).

162. See Malvina Halberstam, United States Ratification of the Convention on the Elimination of All Forms of Discrimination Against Women, 31 GEo. WASH. J. INT'L L. \& EcoN. 49, 55-62 (1997). The reservations are criticized in Ann Elizabeth Mayer, Reflections on the Proposed United States Reservations to CEDAW: Should the Constitution Be an Obstacle to Human Rights?, 23 Hastings CoNST. L.Q. 727, 800-13 (1996). 
rather than judges? Perhaps they would be mere surplusage, ineffective except where a nation already possesses enough political will to make the change in the first place. Alternatively, high-minded principles without independent legal force, such as the principle that "all men are created equal," might indeed be the driving force behind social change.

In a nation with so little experience with hortatory constitutionalism, it is hard to predict what the effect of aspirational provisions would be, but political actors might well feel at least some allegiance to constitutional principles that are not court-enforced. Senatorial opposition to a flagburning amendment, for example, might arise not from a fear that the Court would strike down the amendment, nor from pure self-interest, but rather from an allegiance to conventions about what sort of amendment is im keeping with the spirit of the Constitution. Likewise, presidential impeachment is probably insulated substantively from court review under the political question doctrine, ${ }^{163}$ but during the impeachment proceedings against President William Jefferson Clinton, members of Congress debated the particular metes and bounds of a constitutional limitation on "high Crimes and Misdemeanors." It is less clear whether such heightened constitutional consciousness would extend readily from rare phenomena such as flag-burning and impeachment to inatters concerning gender relations in the structure of everyday life.

\section{CONCLUSION}

American constitutional law operates under strong conventions of constraint to general norms of formal equality, symmetrically interpreted, against state rather than private action, to promote negative not positive rights, that are capable of administrable judicial enforcement. Our hypothetical feminist drafters might be sorely tempted to adopt instead a constitution of women's equality unconstrained by these traditions. They might draft one that is specific, asymmetric, extended to private action and positive rights, and culturally aspirational; one that, in short, looks more like CEDAW, which goes so far as to mandate equality in child-rearing ${ }^{164}$ and the modification of social and cultural prejudices. ${ }^{165}$

The choice between these competing approaches is not a question that may be answered in the abstract; the answer depends on cultural and historical circumstances. Introduction of a highly ambitious constitution into a nation where women are at a low starting point of material well-being is

163. But cf. Nixon v. United States, 506 U.S. 224, 253-54 (1993) (Souter, J., concurring) (contemplating circumstances that "might justify a more searching review of impeachment proceedings").

164. CEDAW, supra note 82, at 29 (art. 16(d), 16(f)).

165. Id. at 17 (art. 5(a)) (requiring such modification "with a view to achieving the elimination of prejudices and customary and all other practices which are based on the idea of the inferiority or the superiority of either of the sexes or on stereotyped roles for men and women"). 
unlikely to jumpstart overnight change. For example, women in India endure low levels of educational and occupational attainment, and remain subject to oppressive ancient marital customs, ${ }^{166}$ despite the Indian Constitution's powerful formal statements of sex equality ${ }^{167}$ On the other hand, even thin constitutional guarantees might dramatically advance sex equality in a nation already primed for change by a period of political and cultural feminist activism, as the example of the United States since the 1970s might be taken to illustrate. The litigation strategy of Ruth Bader Ginsburg and other feminist constitutional lawyers contributed significantly to women's equality despite a paucity of constitutional materials; indeed, the series of equal protection results that began with Reed $v$. Reed resemble a cookbook on what to cook when there's nothing in the kitchen. ${ }^{168}$

To be sure, what American women have gained in equality rests on a patchwork of both state and federal constitutional and statutory provisions, some even enacted by accident (after all, the addition of sex to the protections of Title VII may have began as a southern attempt to incite a filibus$\operatorname{ter}^{169}$ ), and others created with linited ingredients. Yet the rhetoric and the inspiration of broad constitutional guarantees can still aid the gritty trench work of specific statutory and regulatory protection.

The American approach of constitutionalizing woinen's equality from a mimimal text that is general, broad, vague and standard-like, however, plainly allocates considerable discretion to its interpreters. Its efficacy in advancing actual equality therefore depends upon having women or their allies in the room doing the interpreting. To celebrate over an election that produced only five women governors, ${ }^{170}$ thirteen women Senators and

166. See generally Martha C. Nussbaum, Women and Human Development: The CAPABilities ApProach 15-30 (2000).

167. See supra note 3.

168. For a similar metaphor, note Ginsburg's own description of the pre-Reed situation: "Except for the vote... the Constitution remained an empty cupboard for people seeking to promote the equal stature of women and men as individuals under the law." Ginsburg \& Flagg, supra note 35, at 13.

169. See Herma Hill Kay \& Martha S. West, Text, Cases and Materials on Sex-Based Discrimination 579-80 (4th ed. 1996). But see Catharine A. Mackinnon, Sex Equality 17 (2001). MacKinnon commented:

Contrary to widespread inyth, the term 'sex' appears not to have been included in Title VII by accident or as only a joke or as a racist attempt to defeat the entire bill.... The most that can be concluded from available historical sources is that some members of Congress who were not friendly to civil rights preferred a bill, if there was to be one, that prohibited discrimination in employment based on sex as well as race.

Id.

170. See Pat Swif, Gender Gap Loomed Largest in This Election, Bufralo News, Nov. 11, 2000, at D1. The number of governors quickly dropped to four when Governor Christime Todd Whitman of New Jersey resigned to become the administrator of the Environmental Protection Administration, but then rebounded back to five when Jane Swift became Acting Governor of Massachusetts. See Frank Phillips, Transfer of Power: 'Her Excellency' Swift is First Woman to Serve as Mass. Governor, Boston GloBe, Apr. 11, 2001, at A1. 
sixty-one women in the House of Representatives ${ }^{171}$ is sobering; if federal elective office were assessable under Title VII, such statistics might well furnish a prima facie case of discrimination. ${ }^{172}$ The French have just held their first election under a newly adopted constitutional principle of "parity" that actually requires a certaim proportion of women to be placed on the ballot for public office in preference to otherwise available men. ${ }^{173}$ There can be little doubt that the world would look different if half the seats of power had women sitting im them. ${ }^{174}$ In short, constitutionalizing women's equality in the American style can only go so far, dependent as it is upon discretionary interpretation to bring that equality to fruition.

171. Jessica Lee \& Kathy Kiely, New Senate, House Feature Record Number of Women, USA ToDAY, Dec. 19, 2000, at A6.

172. At the state level, only $22 \%$ of state legislators are women. See Robert Tanner, Women Win Big, But Slip in States, TulsA WORLd, Nov. 26, 2000, at 8. At the local level, only one of the nation's twenty-five largest cities has a female mayor. See Judith D. Trunzo, Women's Impact on US Public Policy, INDEPENDENT, Mar. 22, 2001. As for the Oval Office, which has never had a female occupant, note that the current administration has dismantled even such a minor symbolism as the White House Office for Women's Initiatives and Outreach. See Amy Goldstem \& Mike Allen, Women's Outreach Office Closed: Feminist Leaders Decry Bush's Shuttering of Clinton Creation, WASH. Post, Mar. 29, 2001, at A21.

173. See Stuart Jeffries, Elections Put Women in the Spotlight, OBSERver, Mar. 11, 2001, at 26 (noting the "first test of a law passed last year that requires parties to field as many women candidates as men").

174. See SUSAN Estrich, Sex \& POWER 26 (2000) Estrich asked:

Imagine if half the insurance companies were run by women. Would contraceptives be covered? Would legislation be required so women could see a gynecologist? Imagine if half the entertainment companies were run by women. Would there be different video games? Imagime if half the Fortune 500 companies were run by woinen. Would more doors be open to women returning to the workforce? Would men find it easier to take paternity leave? Id.

Would there be inore women in the number two, three and four jobs than there are now? 